УДК 631.453:633.11:631.582(324)

(C) 2013

Корецький О. С., аспірант*

Полтавська державна сільськогосподарська дослідна станція ім. М. І. Вавилова Інституту свинарства і АПВ НААНУ

\title{
БІОЛОГІЧНА АКТИВНІСТЬ ГРУНТУ У ПОСІВАХ ПШЕНИЦІ ОЗИМОЇ ЗАЛЕЖНО ВІД ПОПЕРЕДНИКІВ У ЛІСОСТЕПУ ЛІВОБЕРЕЖНОМУ
}

\section{Рецензент - кандидат сільськогосподарських наук С. В. Поспєлов}

Вивчена залежність біологічної активності трунту у посівах пшенииі озимої від попередників та набору культур у короткоротаційних сівозмінах. Виявлено позитивний вплив бобових попередників еспариету, гороху та сої на біологічну активність трунтових мікроорганізмів у посівах пшениці озимої в сівозмінах із часткою зернових культур 50; 66,7; $100 \%$. У прочесі досліджень було встановлено, щзо розмішення пшениці озимої після пшениці озимої та пару чорного обумовлювало зниження інтенсивності біохімічних прочесів у поверхневих шарах грунту на 17-35\% порівняно з бобовими попередниками.

Ключові слова: біологічна активність, короткоротаційні сівозміни, попередник, пшениия озима, трунт.

Постановка проблеми. На сучасному етапі розвитку землеробства актуальності набуває напрям досліджень мікробіологічних процесів грунту, де важливим компонентом біологічного кругообігу речовин є грунтові мікроорганізми. Вивчення біологічної активності грунту дає змогу вченим більш розширено зрозуміти і виявити закономірності у процесах перетворення органічної речовини, враховуючи антропогенний вплив на грунт та його властивості [7].

Доведено, що крім обробітку грунту, значний вплив на біологічну активність його мають сівозміни, попередники та особливості технологій вирощування культурних рослин. Із зростанням інтенсивності біохімічних процесів підвищується продуктивність сільськогосподарських культур, відбувається накопичення органічної речовини в грунті, покращуються його фізико-хімічні властивості та родючість [2-4].

Аналіз останніх досліджень і публікацій, у яких започатковано розв'язання проблеми. Загальновідомо, що біологічні властивості грунтів безпосередньо залежать від біорізноманіття грунтових мікроорганізмів та функціонування різних еколого-трофічних груп $[6,7]$.

Біологічна активність грунту (БАГ) визначає його родючість, екологічний та фітосанітарний стан. Окрім того мікроорганізми можуть проявляти себе в якості індикатора грунтів. Це дає можливість визначити наявність контамінантів, які впливають на показники біологічної активності, зокрема інтенсивність виділення вуглекислого газу з грунту [4].

Підвищення родючості грунтів у галузі зерновиробництва залежить не тільки від внесення органо-мінеральних компонентів та якості обробітку, але й від дотримання правил підбору попередників, а також правильного ведення короткоротаційних сівозмін $[1,3]$.

Визначення БАГ - важливий показник у процесі ведення моніторингу інтенсивності розкладання органічної речовини, що дає змогу оцінити дію органічних і мінеральних добрив та ефективність впровадження нових технологій вирощування. Крім того визначення показника БАГ сприяє оптимізації поживного режиму грунту та збереження його родючості $[2,8]$.

Мета досліджень - встановлення залежності біологічної активності грунту у посівах пшениці озимої від попередників у короткоротаційних сівозмінах із різним набором та насиченням зерновими культурами.

Завдання полягає у визначенні інтенсивності біологічної активності грунту в шарах $0-30 \mathrm{~cm}$ у посівах пшениці озимої залежно від попередників та частки зернових культур.

Матеріали і методики дослідження. Дослідження виконували у стаціонарному досліді на базі Полтавської державної сільськогосподарської дослідної станції ім. М. І. Вавилова Інституту свинарства і АПВ НААН на чорноземі типовому малогумусному. Орний шар грунту характеризується такими основними агрохімічними і агрофізичними показниками: вміст гумусу $-4,9-5,2 \%$, азоту, що легко гідролізується (за Тюріним і Кононовою) - 119,1-127,1 мг/кг, $\mathrm{P}_{2} \mathrm{O}_{5}$ в оцтовокислій витяжці (за Чиріковим) - 10,0-13,1 мг та обмінного калію (за Масловою) - 17,1-20,0 мг на

* Науковий керівник - доктор сільськогосподарських наук, професор П. І. Бойко 


\section{СТОРІНКА МОЛОДОГО ВЧЕНОГО}

100 г грунту. Реакція грунтового розчину близька до нейтральної (pH 6,9). Насиченість основами коливається в межах 30-40 мг·екв./100 г грунту. Щільність верхнього шару грунту становить

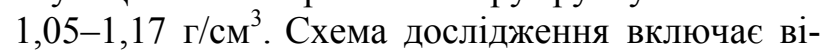
сім трипільних сівозмін (горох - пшениця озима - буряки цукрові; пар чорний - пшениця озима буряки цукрові; горох - пшениця озима - кукурудза; соя - пшениця озима - кукурудза; горох пшениця озима - пшениця озима; горох - пшениця озима - ячмінь ярий; еспарцет піщаний пшениця озима - ячмінь ярий; горох - пшениця озима - соняшник) та три чотирипільні сівозміни (еспарцет піщаний - пшениця озима - буряки цукрові - ячмінь ярий; горох - пшениця озима буряки цукрові - ячмінь ярий; горох - пшениця озима - кукурудза - кукурудза). Насичення зерновими культурами становило: для трипільних сівозмін 33,3-66,7-100\%; для чотирипільних 50-75-100 \%. Технологія вирощування сільськогосподарських культур загальноприйнята для умов зони. Повторність досліду чотириразова.

Біологічну активність грунту визначали за методикою Мішустіна і Петрової [5]. Тривалість експозиції льняного полотна становила 60 діб.

Результати досліджень. Особливістю погодних умов за 2009-2011 рр. досліджень у період експозиції льняного полотна було недостатнє зволоження. Надходження опадів становило близько 35-50 \% від багаторічної норми, а перевищення середньодобової температури повітря 2,2-3,0 ${ }^{\circ} \mathrm{C}$ порівняно $з$ багаторічною.

У процесі оцінки інтенсивності розкладання целюлози у посівах пшениці озимої залежно від попередників було виявлено зниження біологіч- ної активності грунту у шарі $10-20$ см на $1-2,5 \%$ та 20-30 см на $5 \%$ порівняно з верхнім шаром грунту $0-10$ сантиметрів.

Серед трипільних сівозмін найвищу активність розкладання целюлози у посівах пшениці озимої за період досліджень, як у верхньому шаpi (0-10 см), так і в інших шарах (10-30 см) відмічено у сівозміні 7 із попередником еспарцет піщаний, який вирощували після ячменю ярого та після гороху - (сівозміна 8), який вирощували після соняшника. У середньому в орному шарі грунту рівень біологічної активності в цих сівозмінах становив 19,9\% (див. табл.).

Виявлено, що розміщення пшениці озимої у зерно-просапній сівозміні з буряками цукровими (сівозміна 1) обумовлює зниження активності розкладання льняного полотна у всіх досліджуваних шарах і в середньому 17,2 \% від його маси. За повторного розміщенням пшениці озимої (сівозміна 5) біологічна активність грунту виявилася найнижчою (14,2 \%). У ході досліджень було виявлено, що розміщення пшениці озимої після сої (сівозміна 4) із часткою зернових $100 \%$ позитивно впливало на інтенсивність розкладання льняного полотна у нижніх шарах грунту. У поверхневому шарі грунту вона дорівнювала $15,9 \%$, тоді як із поглибленням до 10-20 та 20-30 см - 17,0; 16,6 \% відповідно. Таке явище пояснюється пізнім збиранням сої, порівняно 3 іншими попередниками (гороху, еспарцету, пшениці озимої), недостатніми запасами продуктивної вологи i меншою кількостю рослинних решток на поверхні в той час, як біогенні процеси проходили в нижніх кореневмісних шарах грунту.

Інтенсивність розкладання льняного полотна у посівах пшениці озимої залежно від попередників та насичення зерновими, 2009-2011 рр., \% до вихідної маси

\begin{tabular}{|c|c|c|c|c|c|c|}
\hline \multirow{3}{*}{ 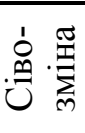 } & \multirow{3}{*}{$\begin{array}{c}\text { Попередник, } \\
\text { передпопередник }\end{array}$} & \multirow{3}{*}{$\begin{array}{c}\text { Частка } \\
\text { зернових у } \\
\text { сівозміні, \% }\end{array}$} & \multicolumn{4}{|c|}{ Інтенсивність розкладання льняного полотна } \\
\hline & & & \multicolumn{4}{|c|}{ шар грунту, см } \\
\hline & & & $0-10$ & $10-20$ & $20-30$ & $0-30$ \\
\hline 2 & Пар чорний - буряки цукрові & 33,3 & 14,2 & 13,9 & 14,4 & 14,2 \\
\hline 1 & Горох - буряки цукрові & 66,7 & 19,2 & 18,1 & 14,3 & 17,2 \\
\hline 7 & Еспарцет - ячмінь ярий & 66,7 & 21,4 & 19,0 & 19,3 & 19,9 \\
\hline 8 & Горох - соняшник & 66,7 & 21,4 & 21,5 & 16,6 & 19,9 \\
\hline 3 & Горох - кукурудза & 100 & 20,0 & 18,2 & 15,1 & 17,8 \\
\hline 4 & Соя - кукурудза & 100 & 15,9 & 17,0 & 16,6 & 16,5 \\
\hline \multirow{2}{*}{5} & Горох - пшениця озима & 100 & 18,7 & 17,1 & 14,5 & 16,8 \\
\hline & Пшениця озима - горох & 100 & 14,2 & 13,7 & 13,3 & 13,7 \\
\hline 6 & Горох - ячмінь ярий & 100 & 18,0 & 17,7 & 16,9 & 17,6 \\
\hline 9 & Еспарцет - ячмінь ярий & 50 & 21,7 & 21,3 & 20,4 & 21,1 \\
\hline 10 & Горох - ячмінь ярий & 75 & 18,9 & 18,3 & 18,6 & 18,6 \\
\hline 11 & Горох - кукурудза & 100 & 21,2 & 21,2 & 17,3 & 19,9 \\
\hline \multicolumn{3}{|c|}{$\mathrm{HIP}_{05}$} & 3,53 & 3,26 & 3,19 & 1,37 \\
\hline
\end{tabular}


СТОРІНКА МОЛОДОГО ВЧЕНОГО

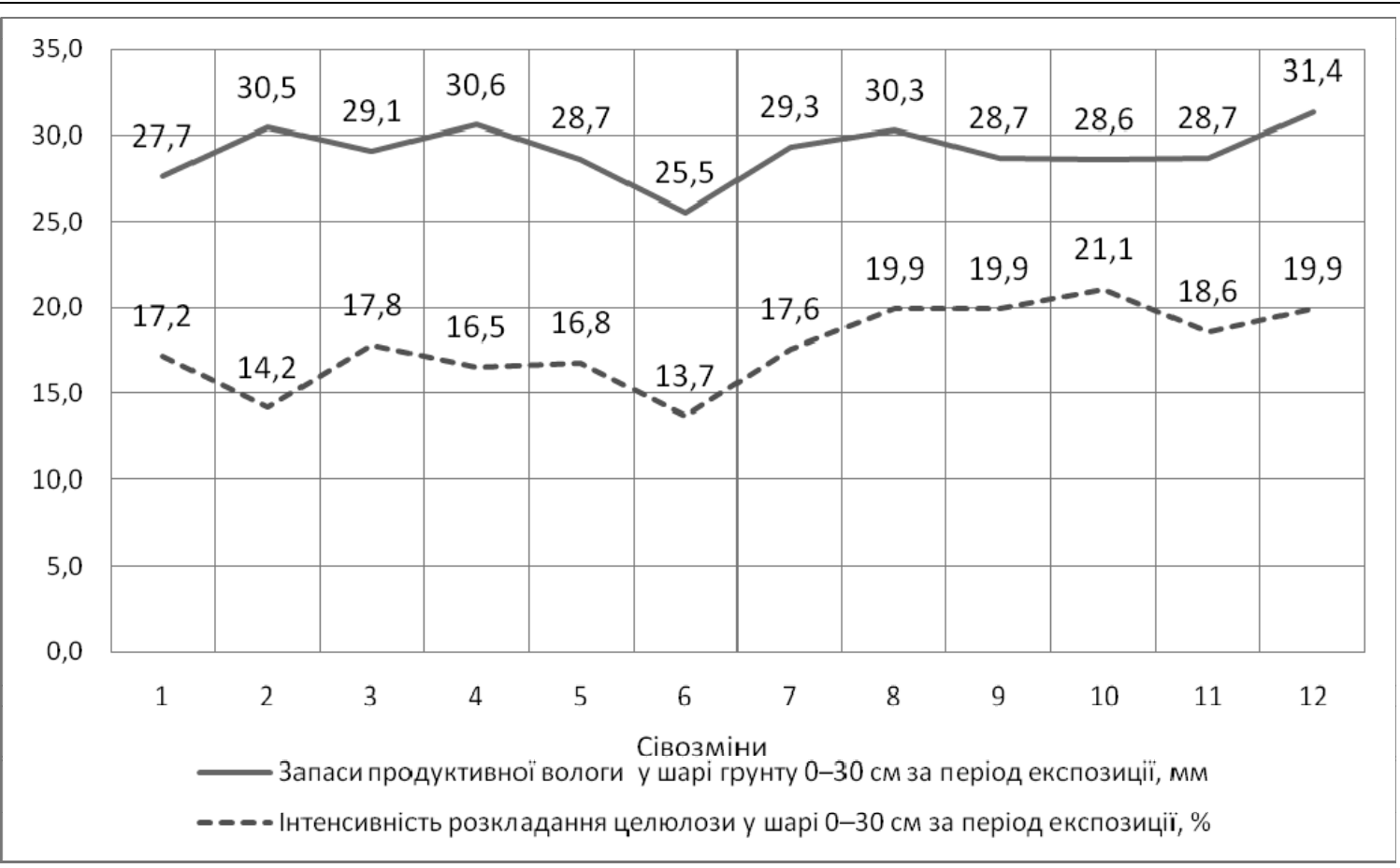

Рис. Інтенсивність розкладання целюлози залежно від вмісту продуктивної вологи в трунті, середне за 2009-2011 pp.

Доведено, що післяжнивні рештки бобових культур містять достатню кількість азоту порівняно зі злаковими і сприяють активізації мікробіологічних процесів та краще мінералізуються [6].

Розміщення поля пару чорного (сівозміна 2) після буряків цукрових призводило до зниження біологічної активності грунту у посівах пшениці озимої, значення якого знаходилося в межах $13,9-14,4 \%$.

Найвищу біологічну активність в орному шарі грунту у посівах пшениці озимої серед чотирипільних сівозмін відмічено після еспарцету, який вирощували на зелений корм і розміщували після буряків цукрових (сівозміна 9) $-21,1 \%$ із часткою зернових $50 \%$. Вирощування пшениці озимої у зерно-просапній сівозміні (11) після гороху 3 двома полями кукурудзи зумовлювало зростання біологічної активності в орному шарі грунту на 6-33\% порівняно із трипільними зерновими сівозмінами.

У процесі аналізу біологічної активності грунту у посівах пшениці озимої було виявлено, що розкладання целюлози перебуває в прямій залежності від вмісту продуктивної вологи в грунті та попередників (див. рис.).

Таким чином, було визначено, що найвища біологічна активність грунту $(21,1 \%)$ досягалась у посівах пшениці озимої після еспарцету (сівозміна 10), де вміст продуктивної вологи в орному шарі грунту становив 28,6 мм, а насичен- ня зерновими становило $50 \%$.

Вирощування пшениці озимої після пшениці озимої зумовлювало порушення водного режиму грунту і цим самим - зниження біологічної активності грунту. Одночасно, оптимальний водний режим створювався за вирощування іï по пару чорному, проте біологічна активність грунту була низькою через недостатню кількість рослинних решток, що обумовлено специфікою попередника.

Отже, розміщення пшениці озимої після кращого попередника у сівозміні з оптимальним насиченням зерновими культурами та дотримання технології вирощування дає змогу підвищити рівень біологічної активності грунту, поліпшити біогенну трансформацію органічної речовини мікроорганізмами й водночас - фітосанітарний стан і родючість грунту.

Висновки. У ході встановлення впливу попередників пшениці озимої на процеси розкладання рослинних компонентів у грунті виявлено:

1. Найвища біологічна активність в орному шарі грунту досягається після бобових трав багаторічних - еспарцету - 18,6 \% та зернобобових гороху та сої - 21,1; 16,5 \% відповідно.

2. За умови вирощування пшениці озимої по пару чорному та після пшениці озимої інтенсивність розкладання целюлози знижується на 1735 \% відносно бобових попередників. 


\section{БІБЛІОГРАФІЯ}

1. Бойко П. І. Екологічно збалансовані сівозміни основа біологічного землеробства / П. І. Бойко, В. О. Бородань, Н. П. Коваленко // Вісник аграр. науки. - 2005. - №2. - С. 9-13.

2. Гангур В. В. Агрономічна та біоенергетична оцінка сівозмін для фермерських господарств Лівобережного Лісостепу України: автореф. дис. ... канд. с.-г. наук; спец. 06.01.01 «Загальне землеробство» / В. В. Гангур. - Дніпропетровськ, 1997. $21 \mathrm{c}$.

3. Зінченко О.I. Рослинництво: підручник / О. І. Зінченко, В. Н. Салатенко, М. А. Білоножко // За ред. О. І. Зінченка. - К. : Аграрна освіта, 2001. $-591 \mathrm{c}$.

4. Іутинська Г. О. Грунтова мікробіологія / Г. О. Іутинська. - К. : Арістей, 2006. - 284 с.
5. Методы почвенной микробиологии и биохимии / Под ред. Д. Г. Звягинцева. - К. : Колос, 1991. - 486 c.

6. Мікроорганізми і альтернативне землеробство / В. П. Патика, І. А. Тихонович, І. Д. Філіп'єв. - К. : Урожай, 1993. - $176 \mathrm{c}$.

7. Симочко Л. Ю. Біологічна активність грунту природних та антропогенних екосистем в умовах низинної частини Закарпаття / Л. Ю. Симочко // Науковий вісник Ужгородського ун-ту. - Ужгород. - 2008. - №22. - С. 152-154.

8. Юркевич $Є$. О. Агробіологічні основи сівозмін Степу України: монографія / Є. О. Юркевич, Н. П. Коваленко, А. В. Бакума. - Одеса: Одеське видавництво «ВМВ», 2011. $-240 \mathrm{c}$. 